\title{
A BRIEF CONSIDERATION OF BRONZE STATUES FROM BALI
}

Most studies of Indonesian bronzes have focused on objects manufactured in Java between the $8^{\text {th }}$ and the $16^{\text {th }}$ centuries. ${ }^{1}$ During the first part of this period, bronzes depicted primarily standing or seated Buddhist or Hindu deities. For some of the earliest images there is still confusion concerning whether the statues were locally produced or imported, but a clearly Javanese style soon developed. By the $10^{\text {th }}$ century we have evidence of the local manufacture of large and elaborate mandalas of deities like those found at LL Nganjuk, East Java. For reasons that are still unclear, by the $12^{\text {th }}$ century, the East Javanese artisans turned away from creating images of deities and toward the production of domestic or ritual implements: vessels, bells, lamps, mirrors, staff finials, etc. This trend is most likely to have been related to changes in religious practice, especially the growing importance of holy water as is still seen in Bali today. ${ }^{2}$

One type of object that has been largely neglected in studies of Indonesian bronzes is images of human figures found on the island of Bali that are thought to date from the $13^{\text {th }}$ to the $17^{\text {th }}$ centuries (fig. 1,2 ). ${ }^{3}$ One reason for the lack of scholarship on these images is that they are extremely rare. I only know of less than two dozen of these bronzes in museum collections or from Dutch archival photographs. ${ }^{4}$ Undoubtedly there are more, which are still considered sacred and stored in temples in Bali. ${ }^{5}$ These statues are particularly interesting because they do not seem to have any sort of counterpart in Javanese art. This paper is a brief exploration of these Balinese bronzes. Where do these figures fit in the chronology of Indonesian and Balinese art? How do they relate to other sculpture from either Java or Bali?

Very little is known about the early history of bronze production in Indonesia. Knowledge of metallurgy seems to have developed in some parts of the archipelago between $300 \mathrm{BC}$ and $700 \mathrm{AD}$. Large bronze drums produced in northern Vietnam have been found from Sumatra to New Guinea. However, there is also evidence of the indigenous manufacture of bronze drums of a different style (sometimes known as the Pejeng style after the Balinese village with the most impressive example). Printing moulds showing similar patterns to those on drums have been found in Manuaba and Sembiran, Bali, and are indications of local manufacture by the first centuries AD. Bronze objects from the early metal age such as jewellery, spearheads, ceremonial tools and weapons have also been found, including in sites in northern Bali. ${ }^{6}$

Hindu and Buddhist bronze statues found in Bali are similar to those found in Java. Some are perhaps imports from South Asia while others are very similar in style to bronzes that were produced in Central Java during the $8^{\text {th }}{ }^{4}$ to ${ }^{1} \mathrm{O}_{\text {es }}$ 


\section{Figure 2}

Male figure, Bali, c. 1400-1700, Bali, Museum Volkenkunde, Leiden, 1403-2752

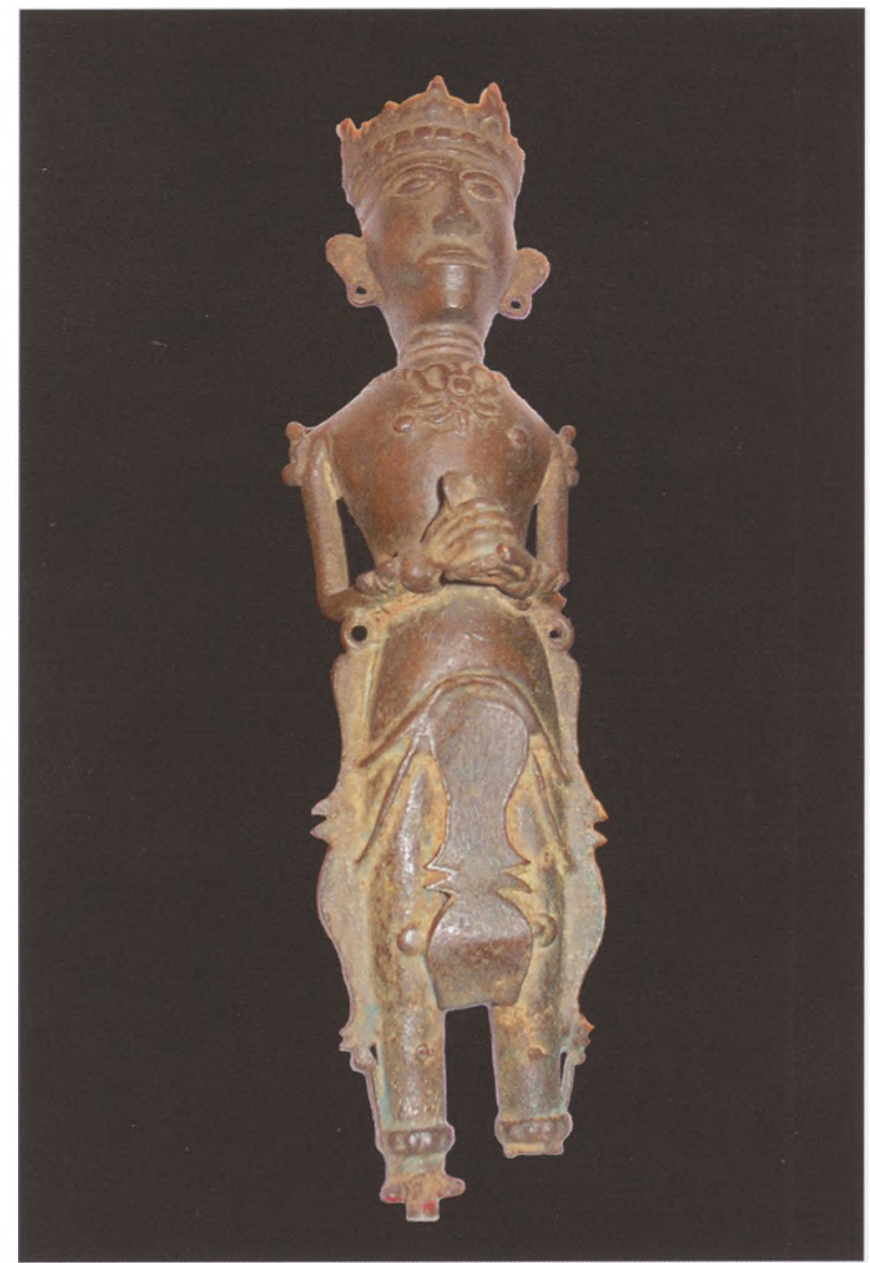

$10^{\text {th }}$ centuries. $^{7}$ It seems clear that a variety of bronze images were considered sacred and the collections found in some Balinese villages and temples have been quite diverse. ${ }^{8}$ However, there are also a number of bronzes that have been found only in Bali and that differ strikingly from Central Javanese images. According to W.F. Stutterheim, these bronzes were considered more sacred to the Balinese than the older bronzes. ${ }^{\circ}$ These statues have often been described as ancestor figures and most do not bear a resemblance to, or carry any attributes of, well-known Hindu or Buddhist deities.

Although there are some exceptions, many of these statues have the same basic characteristics. All of the bronzes depict a male or female figure, standing stiffly upright, and measure between 20 and $50 \mathrm{~cm}$. in height. In several instances male and female figures with similar dress and ornamentation were produced to represent a couple. In most cases the arms are lowered, with forearms bent and hands held, both palms facing up, one on top of the other, in front of the chest (a gesture resembling the mudra of meditation dhyanamudra). On some of the statues there is an object resting on the open palm. In one case this object appears to be a small stupa; in another a rounded form - perhaps a lotus. ${ }^{10}$ 
All of the statues wear elaborate headdresses. A slim band encircling the forehead supports a diadem that flares out into a series of leaf or petalshaped points. Behind this crown, the hair appears gathered into a chignon that is decorated with stylized lotus petals.

The eyes of the statues are open, and accentuated by incised upper eyelids and eyebrows. The ears protrude and are either pierced by a hole or marked by an indentation for the attachment of an earring. Most figures wear a wide necklace with a meandering motif that comes to a point in the middle of the chest. This point is mirrored by a diamond-shaped ornament at the statue's waist. This ornament has a circle at the centre, surrounded by swirling patterns. Decorated bands encircle the very top of the upper arms with ornaments that appear to jut up forming points above the statue's shoulders. Forearms and ankles (if the statue still has them) are also bangled.

The lower body is wrapped in a cloth, which is sometimes decorated with a diamond checkerboard pattern. Two swathes of fabric loop down from hip to hip, bisected by a long sash that falls straight between the legs. On some images, the sashes seem to cascade down the sides of the figures from each hip. A number of figures have small hoops at either hip and at the back of the head; the function of these is not clear. A few statues still stand on openworked double lotus bases, the rest are either broken at the ankle or rest on bare feet.

A number of examples vary from this basic model. A bronze in the Pejeng Museum has a more elaborate headdress and jewellery. ${ }^{11}$ This statue lifts its right hand to the middle of its chest, clasping a rosary, while the left hand, held palm up at waist level, holds an unidentified object. Another statue, illustrated by Ramseyer, is a large male figure with exaggeratedly broad shoulders that was found with six other bronzes at Pura Gaduh in Blahbatuh. It stands with the right arm raised in front of the chest and the left lowered in front of the waist. The headdress, jewellery and clothing of this figure are simple. It is difficult to determine what the statue holds. Two of the other statues from this temple also have unusual features. One has a beard, and the other has four faces and raised arms. ${ }^{12}$

A third image in the Museum Volkenkunde, Leiden, also wears a simple headdress and jewellery and has less prominent facial features. It holds its hands together in front of the waist supporting an unidentified object. An unusual feature of this bronze is the animal skin wrapped around the waist with its head falling between the statue's knees. Animal skins are a mark of an ascetic, and were worn by deities like Shiva.

As stated earlier, these statues do not have any real precedent in Javanese bronzes of either the Central Javanese or East Javanese period. At the time that these images were made, bronze statues of Hindu or Buddhist deities were no longer being produced in Java. ${ }^{13}$ Human figures were still depicted, but primarily as decorative elements on ritual implements. Beautiful examples can be seen as parts of lamps and finials. The only Javanese bronze free-standing human figures from this period that I know of are images of young boys, and these are stylistically very different from the bronze statues from Bali. ${ }^{14}$ 


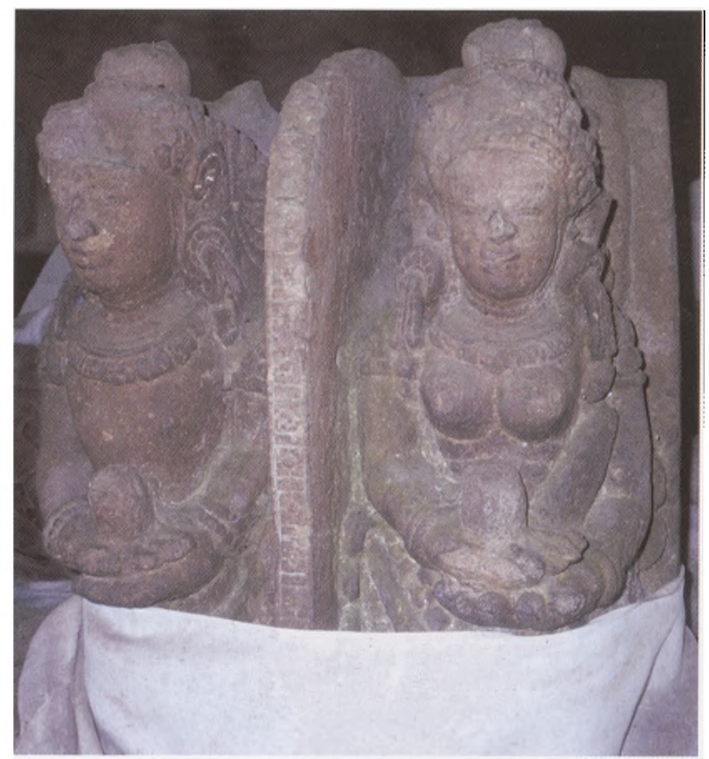

Figure 3

Male and female ancestral figure, Pura Tegah Koripan, Desa Sukawana, Bali, 1011

Figure 4

Male ancestral figure, Pura Tegah Koripan, Desa Sukawana, Bali, c. $1300-1600$

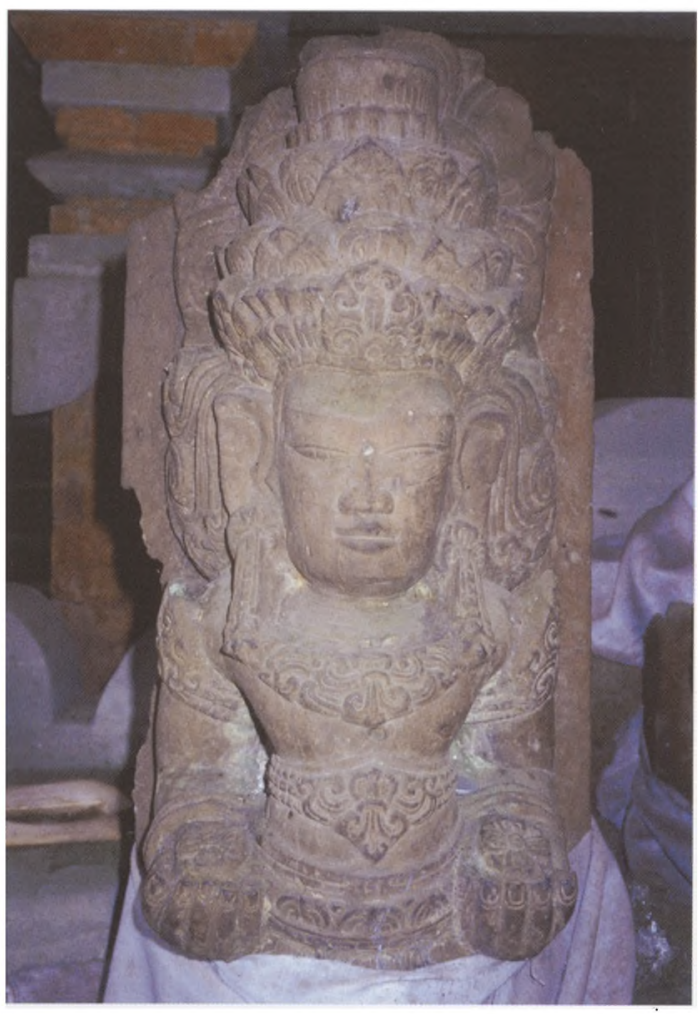

One does find in East Javanese stone sculpture depictions of human figures that bear comparison to these Balinese bronzes. These statues, dating mostly from the late East Javanese period ( $13^{\text {th }}$ to $16^{\text {th }}$ centuries), have been called 'portrait statues' and have been discussed extensively by Marijke Klokke. ${ }^{15}$ These figures stand stiffly upright, often hold their hands in the dhyanamudra, and can be found in paired male-female sets. ${ }^{16}$ Unlike the Balinese bronzes, these figures have four arms and hold attributes of Hindu deities, clearly indicating divine features. Klokke concludes that these images are not portraits of royalty, but 'deification images.' The mudras and downcast eyes of these figures could represent the state of meditation required before unification of a royal figure with a god after death.

Turning to Balinese stone sculpture, one can find objects of closer comparison. ${ }^{17}$ A one metre-high stone image from Pura Tegah Koripan (also known as Pura Sukawana), on Gunung Penulisan, portrays a standing couple separated by a stone divider. Each stands in the same position as the bronze statues, holding a round object in upturned palms (fig. 3). The inscription on the back of the statue names the artist, Mpu Bega, 'Mr. Stutterer,' and a date of 933 Saka or $1011 \mathrm{AD}$. The inclusion of the name of an artist is extremely rare, but this particular one is mentioned in inscriptions on two other sculptures. The jewellery and headdress of a $14^{\text {th }}$ or $15^{\text {th }}$ century statue at the same site is even more similar to the bronze images, but its bent arms are held straight out in front of the body rather than folded in front of the waist (fig. 4). ${ }^{18}$ A comparison can also be made with a few rare examples of Balinese wood sculpture that, despite the tropical climate, appear to have survived for centuries. A statue in the Basel museum is given a date betweencess 
the $13^{\text {th }}$ and $14^{\text {th }}$ centuries, and although very worn, has the same basic characteristics as the bronzes under discussion. ${ }^{19}$

It is interesting to note that the $11^{\text {th }}$-century stone statues from Gunung Penulisan in Bali predate statues of a similar style in Java by two centuries. Despite the parallels in stance and gesture, there are differences between the Balinese and Javanese images. Most of the statues carved by the Balinese neither have multiple arms nor hold attributes associated with deities of Indian pantheons, and thus seem more easily identifiable as human. It would be a worthwhile venture to carbon-date the wood from the archaic looking wood statues in this style as well as conduct thermoluminescence testing on remaining cores of other bronzes of this type to determine if some of these statues might be even older than previously thought.

It is likely that on both islands the standing stone statues were associated with royal ancestor worship, ceremonies consecrating the release of the soul of the deceased ruler into the world of the ancestors. This seems clearly also the case with the bronze sculptures under discussion. A.J. Bernet Kempers writes: 'Their stiffness, facial expression, and attributes of flowers in their hands recall the ancestral figurines and puppets nowadays used in certain rituals, of which they may represent an earlier, more costly version.' ${ }^{20}$ Thus these small images in bronze are most likely continuing a tradition that existed in Bali with stone sculpture from as early as the $11^{\text {th }}$ century. For reasons that are still unclear, at some point around 400 years ago artisans moved from using permanent media like stone and bronze to the ephemeral materials that are used today.

\section{Notes}

1. Notable among the recent scholarship is Pauline Lunsingh Scheurleer and Marijke Klokke's work on the subject. Scheurleer summarizes past scholarship at the beginning of the book. P.C.M. Lunsingh Scheurleer and M.J. Klokke, Ancient Indonesian bronzes; a catalogue of the exhibition in the Rijksmuseum Amsterdam with a general introduction, Leiden/New York, 1988.

2. Lunsingh Scheurleer and Klokke, Op.cit. (note 1), p. 41.

3. Thermoluminescence testing of the core of two statues from the Asian Art Museum in San Francisco produced a date range of 1430-1650.

4. Some examples are in the Museum Bali, MB 3577; Museum Volkenkunde, Leiden, 1403-2752; Asian Art Museum, San Francisco, AAM 86B6a, 86B6b; Museum of Fine Arts, Boston, 1983.327; National Gallery Australia, NGA71.101.28.A-C, NGA 71.101.29.A-B. Other images can be found in W.F. Stutterheim, 'Bronzen beeldjes van Bali', Mededeelingen van de Kirtya Liefrinck-van der Tuuk 2 (1930), p. 3; U. Ramseyer, The art and culture of Bali, Basel, 2002, p. 43; W. Widia, Arca perunggu koleksi Museum Bali, Denpasar, 1980, pp. 11, 14-19. See also Oudheidkundig Dienst photos 9333, 9334, 10811-10817, Inter Documentation Company, Indonesian archaeological photographs on microfiche photo collection of the National Research Centre of Archaeology of the Republic of Indonesia 1901-1956 at the Kern Institute, University of Leiden, Zug, 1982, and other photos in the KITLV database.

5. Because of their sacred nature, many of these statues are kept in locked storehouses or temples and have not been available for research.

6. P. Bellwood, Prehistory of the Indo-Malaysian Archipelago, Canberra, 2007, pp. 29395.

7. For examples see Widia and Proyek Pengembangan Permuseuman Bali (Indonesia), Arca perunggu koleksi Museum Bali. 
8. Oudheidkundige Dienst in Nederlandsch-Indië, Batavia, 1927, pp. 107-08; Stutterheim, Op.cit. (note 4), p. 43.

9. Stutterheim, Op.cit. (noot 4), p. 47.

10. Stutterheim suggests that similar objects depicted in stone are pushpalingas, lingas 'made of flowers, which were employed at the sraddha ceremony as a temporary receptacle of the soul of the deceased prior to its conveyance to heaven by an officiating priest.' W.F. Stutterheim, Indian influences in Old-Balinese art, London, 1935, p. VII; The sraddha ceremony in Majapahit Java is described in the Desawarnana cantos 64-67. Unfortunately the role on statuary in these rituals is not clear. Prapañca and S.O. Robson, Desawamana: (Nagarakrtagama) (Verhandelingen van het Koninklijk Instituut voor Taal-, Land- en Volkenkunde 169 (1995)), pp. 71 74. Puspasarira is another term used for a flower effigy used in Balinese contemporary funerary rituals.

11. A.J. Bernet Kempers, Monumental Bali; introduction to Balinese archaeology \& guide to the monuments, Berkeley/akarta, 1991, fig. 27.

12. The bearded figure has been described as a 'guru' and the four-faced figure as Brahma. This latter image is one of the few that seems to directly allude to a Hindu deity. See Oudheidkundig Dienst photos 9333, 10815, 10816, and 10817. Other bronzes found at Pura Gaduh can be seen in photos 9334, 10811-10817. For a fourfaced figure in stone see the O.D. photo 5672 from Pura Panataran Sasih in Pejeng.

13. One possible exception to this rule are the plaques made depicting the Amoghapasa mandala, commissioned by Krtanegara in the $13^{\text {th }}$ century.

14. Bernet Kempers hypothesizes that these images might have been used in some kind of fertility rituals. A.J. Bernet Kempers, Ancient Indonesian art, Amsterdam, 1959, p. 95, pl. 292-93.

15. M.J. Klokke, 'The iconography of the so-called portrait statues in late East Javanese art', in: M.J. Klokke and P.C.M. Lunsingh Scheurleer (eds.), Ancient Indonesian sculpture (Verhandelingen van het Koninklijk Instituut voor Taal-, Land- en Volkenkunde 165 (1994)), pp. 178-201.

16. Klokke, Op.cit. (note 15), figs. 1,2 .

17. For an in-depth discussion of Balinese stone statuary of this type see Endang Sri Hardiati. Soekatno, 'Arca tidak beratribut dewa di Bali; sebuah kajian ikonografis dan fungsional' (Universitas Indonesia, 1993).

18. For another example of this type see J. Belo (ed.), Traditional Balinese culture, New York, 1970, fig. XVIII.

19. The example from Museum der Kulturen Basel, Ilc, 21157 is illustrated in Ramseyer, Op.cit. (note 4), fig. 38; another example is found in De Kunst van Ball (cat. Haags Gemeentemuseum), Den Haag, 1961, fig. 2.

20. Bernet Kempers, Op.cit. (note 11), p. 68. 